\title{
Increased Plasma Concentrations of Interleukin-1 Receptor Antagonist in Neonatal Sepsis
}

\author{
E. S. J. M. DE BONT, L. H. F. M. DE LEIJ, A. OKKEN, R. BAARSMA, AND J. L. L. KIMPEN \\ Department of Pediatrics [E.S.J.M.D.B., A.O., R.B., J.L.L.K.] and Clinical Immunology [L.L.H.F.M.D.L.], \\ University Hospital Groningen, Groningen, The Netherlands
}

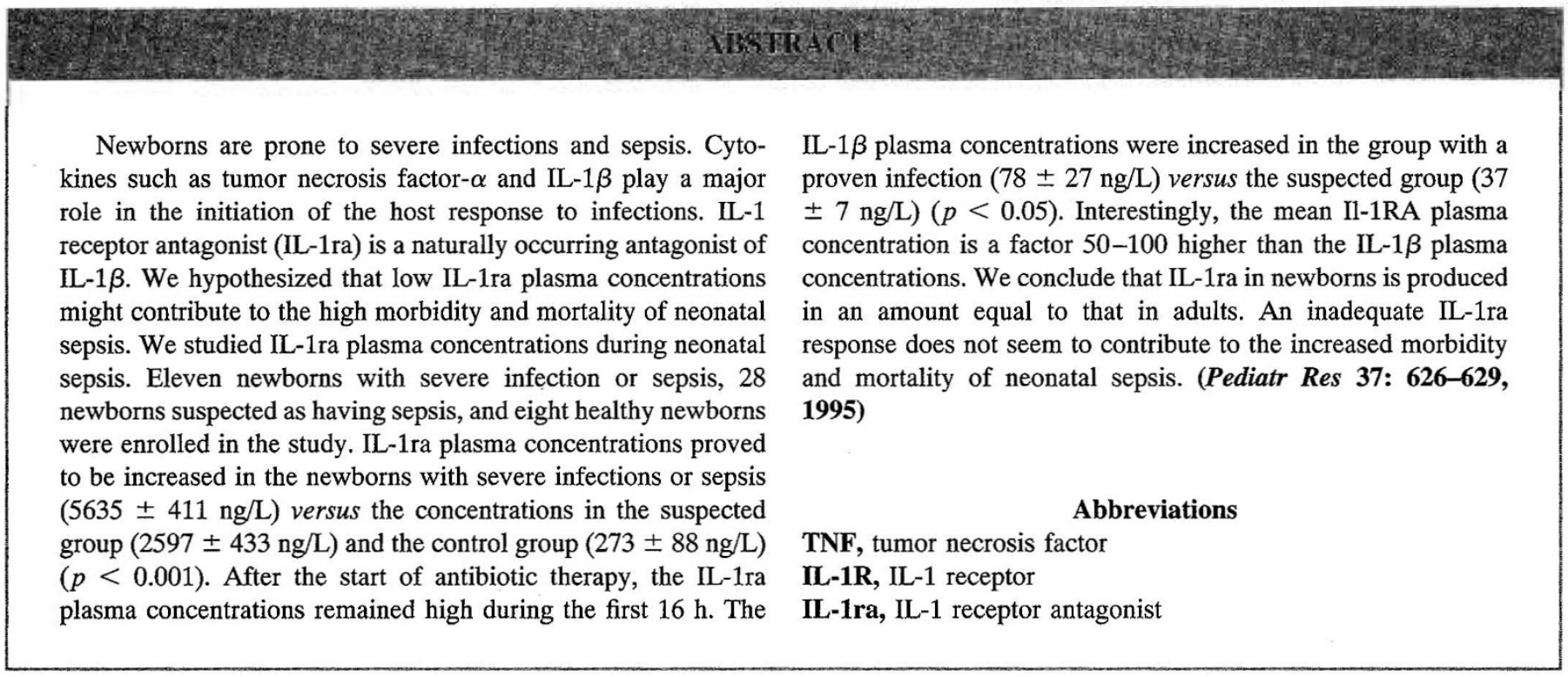

IL-1 is an important pro-inflammatory mediator and initiates in concert with tumor necrosis factor- $\alpha$ (TNF- $\alpha$ ) the systemic host response cascade after infection (1-3). IL-1 potentiates the effect of TNF- $\alpha$ severalfold $(4,5)$. IL- 1 is produced by monocytes in response to various stimuli $(3,6)$. It induces fever and hypotension when given i.v. $(1,7,8)$. Moreover, IL-1 stimulates its own production and that of TNF- $\alpha$ and IL- 6 in the monocyte $(4,9)$. This positive feedback mechanism deteriorates the patients' hemodynamic condition. On the other hand IL-6 suppresses the IL-1 and TNF production in vitro (10). Human IL-1 exists in two active forms: IL- $1 \alpha$ and IL- $1 \beta$, which are structurally related and are produced as precursors (11). Proteases cleave IL- $1 \alpha$ and IL- $1 \beta$ precursors to give rise to the active forms of IL- $1 \alpha$ and IL- $1 \beta$ (11-13). IL- $1 \alpha$ has a function in the monocyte as an autocrine messenger and a function on the cell membrane as a paracrine messenger. IL- $1 \alpha$ is rarely detected in the circulation (11). IL- $1 \beta$ is released in the blood and can be detected in the circulation $(2,3,11)$. Both IL- $1 \alpha$ and IL- $1 \beta$ bind to the IL- 1 receptor (IL-1R), leading to

Received July 14, 1994; accepted December 6, 1994.

Correspondence: J. Kimpen, Beatrix Children's Hospital, University of Groningen, Oostersingel 59, Postbus 30.001, 9700 RB Groningen, The Netherlands.

This study was financial supported by Glaxo BV, Zeist, The Netherlands. several intracellulair processes and clinical phenomena as described elsewhere (11).

IL-1 receptor antagonist (IL-1ra) is a naturally occurring antagonist of IL-1 (14-16). IL-1ra binds competitively to the IL-1R (17). The IL-1ra/IL-1R complex on the cell membrane does not give rise to activation of the cell, as opposed to the IL-1/IL-1R complex. In vitro and in animals IL-1ra blocks IL-1-induced phenomena as TNF- $\alpha$ and IL-6 production, hypotension, and shock $(8,18-20)$. In vitro studies demonstrated that IL-1ra and IL-1 $\beta$ are often produced in the same monocyte, but are regulated differently $(21,22)$.

Thus far no data are available with regard to the role of IL-1ra in the pathogenesis of neonatal sepsis. The aim of the present study was to investigate whether a low IL-1ra plasma concentration is a reason for the high morbidity and mortality during neonatal sepsis $(23,24)$.

\section{METHODS}

Cytokine measurements. EDTA blood specimens were obtained by venipuncture or from an arterial catheter and immediately transported on ice to the laboratory. Plasma was separated from the blood within $30 \mathrm{~min}$. Aliquots were stored at $-80^{\circ} \mathrm{C}$ until assayed. IL-1 $\beta$ was measured using an EASIA assay (Medgenix) for IL-1 $\beta$. IL-1ra was measured with an 
ELISA method (Amersham Corp.). Because of the small blood sample we used an adapted method (100 $\mu \mathrm{L}$ for IL- $1 \beta$ measurements and $50 \mu \mathrm{L}$ for the IL-1ra measurement). The control, interassay, and intraassay values obtained with this procedure were within the same range as the original method. The detection limits were $4 \mathrm{ng} / \mathrm{L}$ for IL- $1 \beta$ and $100 \mathrm{ng} / \mathrm{L}$ for IL-1ra. In the septic group the first blood sample was taken before the start of antibiotic treatment.

Informed consent was obtained from the parents of each newborn before the start of the study. The study was approved by the hospital ethics committee.

Statistical analysis. Differences between groups were analyzed with Wilcoxon-Mann-Whitney test. Differences were considered significant at $p$ values equal or less than 0.05 . All data are expressed as mean \pm SEM.

Patients. During a 12 -mo period 47 consecutive newborns with clinical suspicion of sepsis were included in the study. Patients with bronchopulmonary dysplasia, ventilator dependency for more than $14 \mathrm{~d}$, or indomethacin use were excluded. Signs suggesting sepsis were lethargy, apneic spells, a poor peripheral circulation, and poor feeding (24-26).

Sepsis was defined on clinical grounds and a positive blood culture. These patients and patients with a well-defined severe localized bacterial infection were included in group 1. Patients suspected for sepsis but without a positive blood culture or a localized bacterial infection were included in group 2. Group 3 were healthy newborns admitted for reasons other than infectious or immunologic diseases.

Two IL-1 $\beta$ plasma concentrations are lacking in the septic group due to inadequate sample volume. The antibiotic regime was ampicillin $(50 \mathrm{mg} / \mathrm{kg} / \mathrm{d}$, every $8 \mathrm{~h})$ and ceftazidime $(100$ $\mathrm{mg} / \mathrm{kg} /$ day, every $8 \mathrm{~h}$ ), when newborns became septic in the first $5 \mathrm{~d}$ of life. In newborns aged $7 \mathrm{~d}$ or more and suspected as having sepsis, the initial antibiotic therapy was cefuroxime $(100 \mathrm{mg} / \mathrm{kg} /$ day every $12 \mathrm{~h}$ ) and amikacin (according to gestational age and birth weight every $12 \mathrm{~h}$ ), because of local resistance patterns of nosocomial isolates.

\section{RESULTS}

Eleven out of 47 patients fulfilled the definition for sepsis or had a severe bacterial infection. Nine patients had a positive blood culture, and two patients had a urinary tract infection (seven male and four female newborns, mean gestational age $34.1 \pm 1.4 \mathrm{wk}$, mean birth weight $2.3 \pm 0.5 \mathrm{~kg}$, mean age 11.8 $\pm 4.1 \mathrm{~d}$ ) (group 1) (Table 1). In patient 10, many leukocytes and bacteria were seen in the urine sediment, but the culture was lost. Congenital urinary tract abnormalities were not found. There were no deaths during the study period.

In 28 newborns sepsis was suspected on clinical grounds but not confirmed by culture (group 2) (16 male and 12 female infants, mean gestational age $29.4 \pm 1.9 \mathrm{wk}$, mean birth weight $1.9 \pm 0.1 \mathrm{~kg}$, mean age $7.6 \pm 1.6 \mathrm{~d}$ ). Empirical antibiotic therapy was discontinued after $3 \mathrm{~d}$. All patients but two recovered within a few days. One patient died after $3 \mathrm{~d}$ due to congenital hypoplasia of the lungs, which was confirmed at autopsy. The second patient died after $5 \mathrm{~d}$ due to a therapyreistant coagulation disorder, intracranial hemorrhage, and respiratory insufficiency.

The control group included eight healthy control subjects (three male and five female infants, mean gestational age 35.6 $\pm 1.2 \mathrm{wk}$, mean birth weight $2.1 \pm 0.2 \mathrm{~kg}$, mean age $10.9 \pm$ 4.9 d). Blood for cytokine measurements was obtained once when blood samples were taken for glucose, bilirubin, or hemoglobin measurements.

In Figure 1 the individual IL-1ra plasma concentrations are shown. The mean IL-1ra plasma concentration in the septic group (5635 $\pm 411 \mathrm{ng} / \mathrm{L})$ was significantly higher than the concentrations on the suspected group $(2597 \pm 433 \mathrm{ng} / \mathrm{L})(p<$ $0.001)$ and the control group $(273 \pm 88 \mathrm{ng} / \mathrm{L})(p<0.001)$. The mean IL-1ra plasma concentration in the suspected group was significantly increased versus the control group $(p<0.01)$. After the start of the antibiotic treatment the IL-1ra plasma concentrations remained high during the first $16 \mathrm{~h}$ (data not shown). In comparison with IL-1 plasma concentrations the IL-1ra plasma concentrations was 50-100-fold higher. No correlation is found between IL-1ra and gender or gestational age.

Also the Il- $1 \beta$ plasma concentrations were increased in the septic group (78 $\pm 27 \mathrm{ng} / \mathrm{L})$ versus the suspected group (37 \pm $7 \mathrm{ng} / \mathrm{L})(p<0.05)$ (data not shown), confirming the data of our previous study (27).

Table 1. Clinical data of patient group, group 1

\begin{tabular}{|c|c|c|c|c|c|c|c|c|}
\hline Patient & $\begin{array}{c}\text { Gestational } \\
\text { age (wk) }\end{array}$ & $\begin{array}{c}\text { Birth } \\
\text { weight } \\
\text { (g) }\end{array}$ & Sex & $\begin{array}{l}\text { Age at } \\
\text { diagnosis } \\
\text { (d) }\end{array}$ & Culture & Site & $\begin{array}{c}\mathrm{IL}-1 \beta \\
(\mathrm{pg} / \mathrm{mL})\end{array}$ & $\begin{array}{c}\text { IL-1ra } \\
\text { (pg/mL) }\end{array}$ \\
\hline 1 & 33 & 1510 & M & 6 & Coagulase-negative Staphylococcus & Blood & 20 & 5636 \\
\hline 2 & 36 & 3680 & $\mathrm{~F}$ & 47 & Enterobacter sp. (peritonitis) & Blood & $<4$ & 5024 \\
\hline 3 & 32 & 1295 & $\mathrm{~F}$ & 0 & E. coli & Blood & 232 & 5636 \\
\hline 4 & 40 & 4035 & M & 1 & Listeria monocytogenes & Blood & 29 & 8934 \\
\hline 5 & 31 & 1740 & M & 20 & Coagulase-negative Staphylococcus & Blood & 22 & 6038 \\
\hline 6 & 27 & 1280 & M & 0 & L. monocytogenes & Blood & 196 & 6038 \\
\hline 7 & 30 & 1490 & M & 7 & Enterobacter sp. & Blood & 126 & 5636 \\
\hline 8 & 31 & 1120 & M & 10 & Coagulase-negative Staphylococcus & Blood & ND & 5902 \\
\hline 9 & 33 & 1740 & M & 15 & Staphylococcus aureus & Blood & ND & 4809 \\
\hline 10 & 40 & 4040 & $\mathrm{~F}$ & 2 & UWI & Urine & 47 & 5508 \\
\hline 11 & 42 & 3790 & $\mathrm{~F}$ & 2 & Group B hemolytic Streptococcus & Urine & 29 & 2826 \\
\hline
\end{tabular}




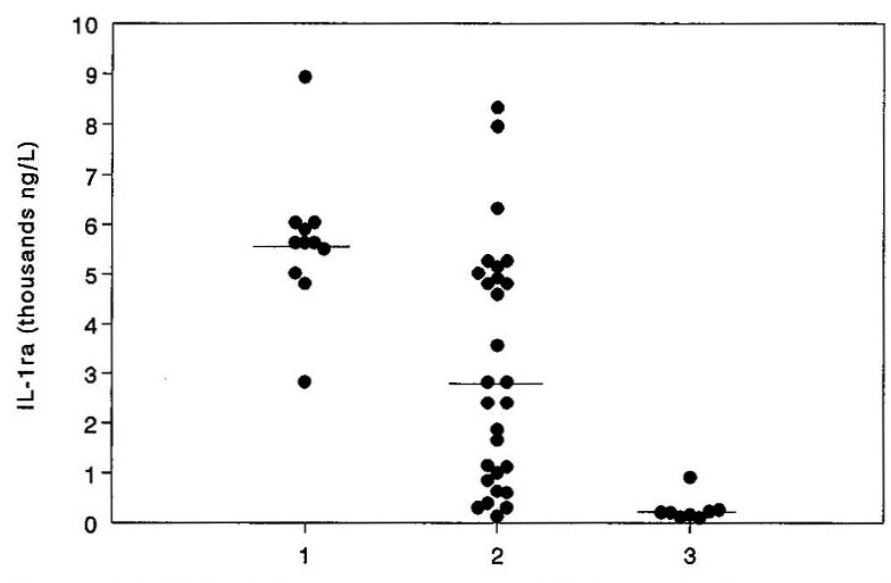

Figure 1. Individual plasma concentrations of IL-1ra for the three groups of newborns: 1 , newborns with confirmed sepsis; 2 , newborns suspected of having sepsis; and 3, control group. Bars indicate median.

\section{DISCUSSION}

This study shows that newborns with infections, bacteremia, and/or sepsis have elevated IL-1ra plasma concentrations, as high as adults during sepsis (28). IL-1ra is a natural occurring inhibitor that blocks the action of IL-1 by competitive binding to its receptor. IL-1ra can block $E$. coli-induced shock in rabbits and baboons when given $15 \mathrm{~min}$ before bacterial infusion $(29,30)$. Experimental evidence suggests that IL-1ra blocks the action of IL- 1 at the level of the IL-1R, because the IL-1 concentrations are not influenced by the presence of IL-1ra $(29,30)$. In addition the IL-1ra infused in baboons attenuated the sustained IL- $1 \beta$ response (30). During in vitro studies with human mononuclear cells, IL-1ra given $30 \mathrm{~min}$ before stimulation inhibits IL-1-induced IL-1, TNF- $\alpha$, and IL-6 production in a dose-dependent manner as well as endotoxininduced cytokine synthesis $(31,32)$. Anderson et al. (22) demonstrated that the peak of IL-1ra production by peripheral blood mononuclear cells was at $4 \mathrm{~h}$ after stimulation. Monocytes can produce IL-1 and IL-1ra at the same time (22). This corresponds with studies in volunteers after experimental endotoxemia and in critically ill patients $(28,33)$.

To our knowledge no study on the role of IL-1ra during neonatal sepsis has been published. An increased morbidity to infection and sepsis in newborns could be due to a low IL-1ra plasma concentration. This was not demonstrated in the present study. The IL-1ra plasma concentrations during infections were as high as in adults. The moderately increased mean IL-1ra plasma concentration in the suspected group of newborns is interesting. It supports the idea that monocytes and macrophages are also activated by other diseases but to a lesser degree than in infectious diseases.

In the septic group the IL-1ra plasma concentrations were 50-100-fold higher than concurrent IL-1 plasma concentrations, confirming data from endotoxemia experiments (28). No correlation between IL-1 $\beta$ and IL-1ra was found. It is possible that IL- $1 \beta$ has a high tissue concentration, and relatively small amounts can be measured in the circulation, whereas IL-1ra has a more systemic distribution.

IL-1 has been proposed as a mediator in preterm labor (34, 35). High IL-1ra concentrations in the amniotic fluid are found
(36). The origin of the high IL-1ra concentrations (range, $10-100 \mu \mathrm{g} / \mathrm{L}$ ) in amniotic fluid is not clear. Recently a gender difference was described; female newborns have higher IL-1ra concentrations in the amniotic fluid and in the urine than do male newborns (37). This gender difference was not found during the present study. Probably the high IL-1ra concentrations in the amniotic fluid are from maternal origin because plasma concentrations in healthy newborns are very low (0.1-1 $\mu \mathrm{g} / \mathrm{L}$ ). Interestingly, recently a gender difference in adults was studied; in adult women with normal ovarian function, the produced and urinary excreted IL-1ra is higher than in men (38).

In conclusion, IL-1ra plasma concentrations are increased during neonatal sepsis in comparison with IL-1ra plasma concentrations of newborns suspected for sepsis or a control group. IL-1ra probably plays a role in reducing the actions of IL-1 during neonatal sepsis. IL-1ra plasma concentrations do not contribute to the increased morbidity and mortality of newborns with sepsis.

\section{REFERENCES}

1. Okusawa S, Gelfand JA, Ikejima T, Connolly RJ, Dinarello CA 1988 Interleukin 1 induces a shock-like state in rabbits. J Clin Invest 81:1162-1172

2. Girardin E, Grau GE, Dayer JM, Roux-Lombard P, The J5 Study Group, Lambert PH 1988 Tumor necrosis factor and interleukin 1 in the serum of children with severe infectious purpura. N Engl J Med 319:397-400

3. Cannon JG, Tompkins RG, Gelfand JA, Michie HR, Stanford GG, vd Meer JWM, Endres S, Lonnemann G, Corsetti J, Chernow B, Wilmore DW, Wolff SM, Burke JF, Dinarello CA 1990 Circulating interleukin-1 and tumor necrosis factor in septic shock and experimental endotoxin fever. J Infect Dis 161:79-84

4. Dinarello CA, Ikejima T, Warner SJ, Orencole SF, Lonnemann G, Cannon JG, Libby P 1987 Interleukin 1 induces interleukin 1. I. Induction of circulating interleukin 1 in rabbits in vivo and in human mononuclear cells in vitro. J Immunol 139:1902-1910

5. Waage A, Espevik T 1988 Interleukin 1 potentiates the lethal effect of tumor necrosis factor $\alpha /$ cachectin in mice. J Exp Med 167:1987-1992

6. Riesenfeld-Orn I, Wolpe S, Garcia-Bustos JF, Hoffmann MK, Tuomanen E 1989 Production of interleukin-1 but not tumor necrosis factor by human monocytes stimulated with pneumococcal cell surface components. Infect Immun 57:1890-1893

7. Smith J, Urba W, Steis R, Janik J, Fenton B, Sharfman W, Conlon K, Sznol M, Creekmore S, Wells N, Elwood L, Keller J, Hestal K, Ewel C, Rossio J, Kopp W, Shimuzut M, Oppenheim J, Longo D 1990 Interleukin-1 $\alpha$ : results of a phase 1 toxicity and immunomodulatory trial. J Am Soc Clin Oncol 9:717

8. Fisher E, Marano MA, v Zee KJ, Rock CS, Hawes AS, Thompson WA, DeForge L, Kenney JS, Remick DG, Bloedow DC, Thompson RC, Lowry SF, Moldawer LL 1992 Interleukin-1 receptor blockade improves survival and hemodynamic performance in Escherichia coli septic shock, but fails to alter host responses to sublethal endotoxemia. J Clin Invest 89:1551-1557

9. Ikejima T, Okusawa S, Ghezzi P, van der Meer JWM, Dinarello CA 1990 Interleukin-1 induces tumor necrosis factor (TNF) in human peripheral blood mononuclear cells in vitro and a circulating TNF-like activity in rabbits. J Infect Dis 162:215-223

10. Schindler R, Mancilla J, Endres S, Ghorbani R, Clark SC, Dinarello CA 1990 Correlations and interactions in the production of interleukin-6 (IL-6), IL-1, and tumor necrosis factor (TNF) in human blood mononuclear cells: IL-6 suppresses IL-1 and TNF. Blood 75:40-47

11. Dinarello CA 1991 Interleukin-1 and interleukin-1 antagonism. Blood 77:1627-1652

12. Cerretti DP, Kozlosky CJ, Mosley B, Nelson N, van Ness K, Greenstreet TA, Maech CJ, Kronheim SR, Druck T, Cannizzaro LA. 1992 Molecular cloning of the interleukin- $1 \beta$ converting enzyme. Science $256: 97-100$

13. Thornberry NA, Bull HG, Calaycay JR, Chapman KT, Howard AD, Kostura MJ, Miller DK, Molineaux SM, Weidner JR, Aunins J, Elliston KO, Ayala JM, Casano FJ, Chin J, Ding GJ-F, Egger LA, Gaffney EP, Limjuco G, Palyha OC, Raju SM, Rolando AM, Salley JP, Yamin T-T, Lee TD, Shivley JE, MacCross M, Mumford RA, Schmidt JA, Tocci MJ. 1992 A novel heterodimeric cysteine protease is required for interleukin-1 $\beta$ processing in monocytes. Nature 356:768-774

14. Seckinger P, Lowenthal JW, Williamson K, Dayer J-M, MacDonald HR 1987 A urine inhibitor of interleukin 1 activity that blocks ligand binding. J Immunol 139:15461549

15. Hannum CH, Wilcox CJ, Arend WP, Joslin FG, Dripps DJ, Heimdal PL, Armes LG, Sommer A, Eisenberg SP, Thompson RC 1990 Interleukin-1 receptor antagonist activity of a human interleukin-1 inhibitor. Nature 343:336-340

16. Granowitz EV, Santos AA, Poutsiaka DD, Cannon JG, Wilmore DW, Wolff SM, Dinarello CA 1991 Production of interleukin-1-receptor antagonist during experimental endotoxaemia. Lancet 338:1423-1424 
17. Granowitz EV, Clark BD, Mancilla J, Dinarello CA 1991 Interleukin-1 receptor antagonist competitively inhibits the binding of interleukin-1 to the type II interleukin-1 receptor. J Biol Chem 266:141-147

18. Granowitz EV, Clark BD, Vannier E, Callahan MV, Dinarello CA 1992 Effect of interleukin-1 (IL-1) blockade on cytokine synthesis. I. IL-1 receptor antagonist inhibits IL-1-induced cytokine synthesis and blocks the binding of IL-1 to its type II receptor on human monocytes. Blood 79:2356-2363

19. Granowitz EV, Vannier E, Poutsiaka DD, Dinarello CA 1992 Effect of interleukin-1 (IL-1) blockade on cytokine synthesis. II. IL-1 receptor antagonist inhibits lipopolysaccharide-induced cytokine synthesis by human monocytes. Blood 79:2364-2369

20. Ohlsson K, Björk P, Bergenfeldt M, Hageman R, Thompson R 1990 interleukin-1 receptor antagonist reduces mortality from endotoxin shock. Nature 348:550-552

21. Poutsiaka DD, Clark BD, Vannier E, Dinarello CA 1991 Production of interleukin-1 receptor antagonist and interleukin- $1 \beta$ by peripheral bood mononuclear cells is differentially regulated. Blood 78:1275-1281

22. Andersson J, Björk L, Dinarello CA, Towbin H, Andersson U 1992 Lipopolysaccharide induces human interleukin-1 receptor antagonist and interleukin-1 production in the same cell. Eur J Immunol 22:2617-2623

23. Quie PG 1990 Antimicrobial defenses in the neonate. Semin Perinatol 14 (suppl 1):2-9

24. Klein JO, Marcy SM 1983 Bacterial sepsis and menigitis In: Remington JS, Klein JO (eds) Infectious Diseases of the Fetus and Newborn Infant, 2nd Ed. WB Saunders, Philadelphia, pp 679-699

25. McCracken GH Jr 1981 Bacterial and viral infections of the newborn. In: Avery GB (ed) Neonatology, 2nd Ed. JB Lippincott, Philadelphia, pp 723-733

26. Overall JC Jr 1987 Infections of the newborn. In: R. E. Behrmann and Vaughan (eds) Nelson Textbook of Pediatrics, 13th Ed. WB Saunders, Philadelphia, pp 425-427

27. de Bont ESIM, Martens A, van Raan J, Samson G, Fetter WPF, Okken A, de Leij LHFM 1993 Tumor necrosis factor $\alpha$, interleukin $1 \beta$, and interleukin 6 plasma levels in neonatal sepsis. Pediatr Res 1993 33;380-384

28. Granowitz EV, Santos AA, Poutsiaka DD, Cannon JG, Wilmore DW, Wolff SM, Dinarello CA 1991 Production of interleukin-1-receptor antagonist during experimental endotoxaemia. Lancet 338:1423-1424
29. Wakabayashi G, Gelfand JA, Burke JF, Thompson RC, Dinarello CA 1991 A specific receptor antagonist for interleukin 1 prevents Escherichia coli-induced shock in rabbits. FASEB J 5:338-343

30. Fischer E, Marano MA, Van Zee KJ, Rock CS, Hawes AS, Thompson WA, DeForge L, Kenney JS, Remick DG, Bloedow DC, Thompson RC, Lowry SF, Moldawer LI 1992 Interleukin-1 receptor blockade improves survival and hemodynamic performance in Escherichia septic shock, but fails to alter host responses to sublethal endotoxemia. J Clin Invest 89:1551-1557

31. Granowitz EV, Clark BD, Vannier E, Callahan MV, Dinarello CA 1992 Effect of interleukin-1 blockade on cytokine synthesis. I. IL-1 receptor antagonist inhibits IL-1-induced cytokine synthesis and blocks the binding of IL-1 to its type II receptor on human monocytes. Blood 79:2356-23563

32. Granowitz EV, Vannier E, Poutsiaka DD, Dinarello CA 1992 Effect of interleukinblockade on cytokine synthesis. II. IL-1 receptor antagonist inhibits lipopolysaccharide-induced cytokine synthesis by human monocytes. Blood 79:2364-2369

33. Fischer E, Van Zee KJ, Marano MA, Rock CS, Kenney JS, Dinarello CA, Lowry SF, Moldawer LL 1992 Interleukin-1 receptor antagonist circulates in experimental inflammation and in human disease. Blood 79:2196-2200

34. Romero R, Mazor M, Brandt F, Sepulveda W, Avila C, Cotton DB, Dinarello CA 1992 Interleukin- $1 \alpha$ and interleukin- $1 \beta$ in preterm and term human parturition. Am J Reprod Immunol 27:117-123

35. Romero R, Mazor M, Tartakovsky B 1991 Systemic administration of interleukin-1 induces preterm parturition in mice. Am J Obstet Gynecol 165:969-971

36. Romero R, Sepulveda W, Mazor M, Brandt F, Cotton DB, Dinarello CA, Mitchell MD 1992 The natural interleukin-1 receptor antagonist in term and preterm parturition. Am J Obstet Gynecol 167:863-872

37. Bry K, Lappalainen U, Waffarn F, Teramo K, Hallman M 1993 Influence of fetal gender on the concentration of interleukin-1 receptor antagonist in amniotic fluid and in newborn urine. Pediatr Res 35:130-134

38. Lynch EA, Dinarello CA, Cannon JG 1994 Gender differences in IL- $1 \alpha$, IL- $\beta$, and IL-1 receptor antagonist secretion from mononuclear cells and urinary excretion. $J$ Immunol 153:300-306 